\title{
PERNIKAHAN DI KALANGAN MAHASISWA S-1
}

\author{
Galuhpritta Anisaningtyas ${ }^{\left.1)^{*}\right)}$ dan Yulianti Dwi Astuti ${ }^{2 * *)}$ \\ ${ }^{1,2)}$ Program Studi Psikologi Fakultas Psikologi dan IImu Sosial Budaya Universitas Islam Indonesia \\ ${ }^{*}$ Email: pritta 87@ yahoo.co.id \\ ${ }^{* *}$ Email: yulianti@fpsi.uii.ac.id
}

\begin{abstract}
Abstrak
Penelitian ini bertujuan untuk mengetahui seluk beluk pernikahan di kalangan mahasiswa strata 1 (S1) dengan fokus pada motivasi menikah, faktor-faktor yang menyebabkan terbentuk atau teraktual isasinya motivasi tersebut dan bagaimana kehidupan mereka setelah pernikahan. Responden dalam penelitian ini berjumlah tiga orang dengan karakteristik mahasiswi S1, berstatus sebagai mahasiswa aktif, berusia 18-22 tahun, telah menikah dan tinggal bersama suami serta tidak bercerai sampai saat penelitian ini dilakukan.Metode pengambilan data yang digunakan adalah wawancara dengan menggunakan interview guide sebagai panduan dalam percakapan. Metode analisis data dalam penelitian ini adalah analisis kualitatif, dengan langkah-langkah berupa wawancara, transkrip verbatim, pembuatan tematema yang kemudian akan dilanjutkan dengan memasukkan ke dalam sub kategori dan kategori untuk memperoleh model pernikahan di kalangan mahasiswa S1. Berdasarkan hasil penelitian, disimpulkan bahwa secara umum responden menikah di saat masih kuliah karena memiliki motivasi yang kuat untuk menikah yang didukung oleh faktor-faktor seperti dukungan dan restu dari orangtua serta keyakinan pada diri sendiri untuk menjalani pernikahan sambil kuliah. Secara umum, kehidupan pernikahan mahasiswa yang menikah di saat masih kuliah dalam keadaan baik meskipun mereka mengalami kesulitan dalam mengatur waktu antara kuliah dan rumah tangga dan kadangkala kehidupan pernikahan diwarnai dengan konflik-konflik kecil.
\end{abstract}

Kata kunci: motivasi, pernikahan, kehidupan pernikahan

\section{MARRIAGE AMONG UNDERGRADUATE STUDENTS}

\begin{abstract}
This study aimed to understand the trend to get married among undergraduate students with a focus on their motivation to get married, the factors that lead to the making or the actualization of that motivation, and how their life after marriage. Respondents in this study were 3 female undergraduate students aged 18-22 years old, married and lived with her husband, and did not divorce at the time of this study held. The data collected by interview using the interview guide as guide the conversation. The study employed qualitative analysis with measurement in the interview forms, verbatim transcripts, making the themes which will then be followed by entering into a sub category and category to obtain a model of marriage among undergraduate students. Based on the results, it is concluded that in general the respondents were married while they were still in college because they had a strong motivation for being married and also supported by factors such as the support and blessing of the parents as well as confidence in their self to live a marriage while in college. In general, their marriage life in good condition, although they have difficulty in managing the time between college-family and their marriage life that sometimes tinged with minor conflicts.
\end{abstract}

Keywords: motivation, marriage, marriage life 


\section{Pendahuluan}

Pernikahan adalah satu pokok yang terpenting untuk hidup dalam pergaulan yang sempurna yang diridhoi Allah SWT dan dari sanalah terwujudnya rumah tangga bahagia yang menelurkan keluarga sejahtera. Kesejahteraan hidup lahir batin menjadi idaman setiap keluarga dan itulah yang menjadi pokok keutamaan hidup (Salim, 1980). Pernikahan juga diatur dalam Undang-undang pemerintahan yang dijelaskan pada pasal 1 Undang-Undang 1/1974 bahwa pernikahan adalah suatu ikatan lahir batin antara seorang pria dan wanita sebagai suami dan istri dengan tujuan membentuk keluarga yang bahagia dan kekal berdasarkan Ketuhanan Yang Maha Esa. Pernikahan merupakan unsur penting dalam kehidupan bangsa. Tujuan pernikahan itu sendiri adalah mendapatkan kebahagiaan, cinta kasih, kepuasan dan keturunan (M unandar, 2001).

Menurut sebagian besar ulama figh, hukum menikah terkait dengan kondisi kesiapan mempelai. M enikah hukumnya bisa sunnah, wajib, makruh dan bahkan bisa pula haram. Ibn Daqiq al-'Id menjelaskan bahwa nikah menjadi wajib ketika seseorang merasa sangat tergantung untuk menikah. Jika tidak dilakukan, ia bisa terjerumus pada perzinaan. Nikah juga bisa haram, ketika pernikahan menjadi ajang penistaan terhadap istri ataupun suami, baik dalam hal nafkah lahir maupun batin. Menjadi sunnah, jika ia tidak tergantung terhadap menikah, tetapi bisa mendatangkan manfaat baginya. Jika menikah tidak mendatangkan manfaat, maka hukumnya justru menjadi makruh (www.noped.net). Lain halnya Abdussalam (2006) yang menjelaskan mampu menikah yang diartikan oleh masyarakat sebagai siap secara fisik dan materi. Parameter lahiriah lebih sering menjadi tolak ukur, termasuk kesiapan pekerjaan mapan, pendapatan yang cukup, rumah dan kemampuan menghidupi keluarga.

Menikah atau mempersiapkan diri untuk menikah merupakan tugas perkembangan masa remaja akhir atau dewasa awal, yakni antara usia 18 sampai 22 tahun. Yang dimaksud dengan tugas perkembangan adalah segala sesuatu yang harus dicapai oleh individu pada suatu tahap perkembangan (Adhim, 2002). Kehidupan psikososial dewasa awal/muda semakin kompleks dibandingkan dengan masa remaja karena selain bekerja, mereka akan memasuki kehidupan pernikahan, membentuk keluarga baru, memelihara anak-anak dan tetap harus memperhatikan orang tua (Dariyo, 2003).

Papalia dan Olds (Adhim, 2002) mengemukakan usia terbaik untuk menikah bagi perempuan adalah 19-25 tahun, sedangkan laki-laki usia 20-25 tahun. Rentang usia 18 sampai 22 tahun merupakan usia seseorang yang memasuki atau berada pada jenjang pendidikan di perguruan tinggi yaitu strata 1 (S1). Hoffman dkk (Adhim, 2002) menulis satu bahasan khusus tentang menikah pada usia dewasa muda (young adulthood), yakni dari usia 18 tahun sampai sekitar 24 tahun. Angka statistik di Amerika menunjukkan 34,6\% perempuan pada usia 20-24 tahun dan 21,4\% laki-laki dengan usia yang sama melakukan pernikahan, sementara mereka masih menempuh studi di perguruan tinggi. Sebagian besar golongan dewasa awal/muda sedang atau telah menyelesaikan pendidikan sampai taraf universitas dan kemudian mereka merasa segera memasuki jenjang karier dalam pekerjaannya.

Menikah selagi masih menjalani kuliah sepertinya saat ini sedang menjadi trend di kalangan generasi muda. Namun, kebanyakan masyarakat masih memandang aneh mahasiswa yang 
memutuskan untuk menikah di saat masih kuliah. Bagi mereka, menikah saat masih kuliah dianggap keputusan yang tak berdasar. Di lain pihak, hasil penelitian sosial yang dipublikasikan cukup mengusik kekhawatiran para orangtua. Mereka khawatir anak-anak mereka masuk dalam 20\% dari 1.000 remaja yang pernah melakukan seks bebas. M enurut sebuah penelitian di Bandung (Pikiran Rakyat, 08/08/04), 21-30\% remaja Indonesia di kota besar pernah melakukan seks pranikah menurut hasil survey yang dikutip BKKBN. Jika anak mereka masuk dalam bilangan $20 \%$ itu, maka pendidikan dan masa depannya terancam karena terpaksa menikahkannya disebabkan "kecelakaan". Maka tidak heran kalau dalam penelitian yang sama, 90\% dari remaja putri yang hamil pranikah memilih jalan aborsi demi "menyelamatkan" masa depannya. Lagi-lagi, langkah "penyelamatan" yang dilakukan itu sarat dengan motif materialistik dan prestise sosial. Memang sulit mengasumsikan pasangan remaja yang mayoritas masih belum mandiri secara ekonomis itu mampu menjalani hidup rumah tangga secara normal (www.endonesa.net/utty/2008/20/09/dibalik-trend-nikah-dini-di-kalanganremaja-muslim-perkotaan).

Sebuah situs internet (problematikaremaja.blogspot.com/2007/12/muslimah-antara-siapingin-menikah) menuliskan bahwa untuk mengambil keputusan menikah diperlukan persiapanpersiapan yang mendalam, seperti:

Pertama, kesiapan pemikiran yang mencakup: a). Kematangan Visi Keislaman; Hal ini dimaksudkan, agar pasangan suami istri mempunyai frame yang sama mengenai Islam sebagai dasar rumah tangga, agar rumah tangga benar-benar bernilai ibadah, tidak hanya sebagai pemuas kebutuhan biologis saja. b). Memiliki kematangan visi kepribadian; Disamping beragama secara kultural, banyak juga orang yang landasan keislamannya di bangun oleh emosi. Jika hal ini terjadi dalam rumah tangga, bisa menjadi sebab timbulnya kegagalan seseorang dalam berumah tangga.

Kedua, kesiapan psikologis. Kematangan psikologis yang dimaksud adalah kematangan atau kesiapan tertentu secara psikis, untuk menghadapi berbagai tantangan yang akan dihadapi selama hidup berumah tangga.

Ketiga, kematangan fisik. Ada beberapa hal yang menjadi persyaratan mutlak dalam sebuah perkawinan menurut Islam, yang berkaitan dengan fisik, antara lain: a). Seorang laki-laki atau wanita yang akan menikah harus yakin bahwa alat-alat reproduksinya berfungsi dengan baik. Karena salah satu sebab perceraian yang diperbolehkan dalam Islam adalah karena alat reproduksi pasangannya tidak berfungsi dengan baik. b). Usia; Hal juga harus disadari, bahwa secara fisik benar-benar sudah siap menikah. Itulah mengapa sebabnya seorang wanita dianjurkan untuk tidak menikah dalam usia yang masih dini. c). Kesehatan; Ketika seseorang memutuskan untuk menikah, hal yang juga harus diperhatikan adalah seputar kesehatan termasuk pada kondisi fisik dan kesehatan calon pasangan. Dan juga perlu diketahui kesehatan keluarga calon pasangan, hal ini dimungkinkan terdapatnya suatu penyakit tertentu yang merupakan penyakit keturunan.

Keempat, kesiapan ekonomi. Perkawinan juga merupakan kerja ekonomi, tidak hanya cukup dengan cinta. Bukan berarti seseorang harus materialistis. Namun hal ekonomi kadang menjadi pemicu konflik dalam rumah tangga. 
Pertanyaannya adalah apakah seorang mahasiswa yang masih duduk di bangku kuliah dan berusia muda sudah memiliki semua hal yang diperlukan dalam sebuah pernikahan? Begitu banyak permasalahan yang bisa terjadi dalam sebuah pernikahan apalagi pelaku pernikahan ini adalah seorang mahasiswa yang notabene belum menyelesaikan kuliahnya. Permasalahan yang dialami salah satunya adalah perceraian. Berdasarkan data sejak Januari hingga Agustus 2007, tercatat 117 kasus perceraian usia muda di Kota Bandung akibat hubungan rumah tangga yang tidak harmonis. Bahkan, 90\% kasus perceraian dilakukan pasangan suami istri usia muda (www.bapeda-jabar.go.id.bapeda_design_informasi). Selain masalah perceraian, saat ini yang banyak diperbincangkan adalah "menikah muda sebagai ladang kanker". HPV (human papilloma virus) dapat menginfeksi semua orang karena HPV dapat menyebar melalui hubungan seksual (www.kompas.com-2008-01-31-saatnya-mencegah-kanker-serviks). Berbeda dengan persoalan klasik manusia yaitu masalah ekonomi yang lebih sering menjadi faktor utama permasalahan dalam pernikahan terlebih pernikahan tersebut dilakukan pada saat masih menjalani perkuliahan.

Berdasarkan data-data dan fakta yang telah disebutkan di atas, trend menikah ketika masih kuliah ini sangat menarik untuk diteliti, oleh karena itu peneliti ingin mengetahui apa motivasi untuk menikah pada saat masih kuliah, faktor-faktor apa saja yang mendukung terbentuknya atau teraktualisasinya motivasi tersebut dan bagaimana kehidupan setelah pernikahan.

Hurlock (Zein dan Suryani, 2005) memberi pengertian pernikahan atau perkawinan adalah suatu penyatuan jiwa dan raga dua manusia berlawanan jenis dalam suatu ikatan yang suci dan mulia di bawah lindungan hukum dan Tuhan Yang Maha Esa. Pendapat Herning (Munandar, 2001) mengatakan bahwa pernikahan adalah suatu ikatan antara pria dan wanita yang permanen, ditentukan oleh kebudayaan dengan tujuan mendapatkan kebahagiaan. Ketertarikan bersifat persahabatan dan ditandai oleh perasaan bersatu dan saling memiliki.

Menurut Adhim (2002) rentang usia menikah dalam arti menikah di usia kuliah jenjang strata 1 (S1) yang sesuai dengan masa perkembangannya adalah ketika meninggalkan remaja akhir dan memasuki dewasa awal yaitu 18 sampai 22 tahun.

Berdasarkan beberapa pengertian di atas, peneliti menyimpulkan bahwa pengertian pernikahan adalah ikatan lahir batin antara pria dan wanita melalui suatu penyatuan jiwa dan raga untuk mendapatkan kebahagiaan dan kesempatan untuk mendapatkan keturunan. Sedangkan pengertian pernikahan di kalangan mahasiswa strata (S1) adalah pernikahan yang dilakukan pada rentang usia 18 sampai 22 tahun yang juga diatur dalam Undang-Undang Perkawinan dengan batasan minimal umur untuk menikah adalah laki-laki berusia 19 tahun sedangkan wanita berusia 16 tahun.

Carter dan McGoldrick dalam Santrock (2002) mengungkapkan tahap siklus kehidupan keluarga, proses emosianal dari transisi dan perubahan status keluarga yang memerlukan proses yang terus berkembang, yaitu: a). Meninggalkan rumah; orang dewasa muda hidup sendiri. Menerima tanggungjawab emosianal dan keuangan bagi diri sendiri; b).Penggabungan keluarga melalui pernikahan atau memiliki pasangan baru. Individu mempunyai komitmen pada sistem baru; c). Menjadi orangtua dan keluarga dengan anak. Kemampuan menerima anggota baru ke dalam sistem tersebut; d). Keluarga dan anak remaja. Meningkatnya 
fleksibilitas batas-batas keluarga mencakup kemandirian anak dan kelemahan kakek-nenek; e). Kehidupan pada keluarga tengah baya. Menerima keluar dan masuknya anggota ke dalam sistem keluarga; f). Keluarga pada kehidupan lanjut. Menerima pergeseran peran antar generasi; g). Menyiapkan diri untuk kematian diri sendiri. M eninjau hidup dan integrasi

Mahasiswa strata 1 (S1) sudah atau sedang melalui fase pertama yaitu meninggalkan rumah dan menjadi orang dewasa yang hidup sendiri (leaving home and becoming a single adult). Fase pertama ini melibatkan pelepasan (launching) yaitu proses dimana orang muda menjadi orang dewasa dan keluar dari keluarga asalnya. Periode pelepasan adalah waktu bagi kaum muda dan orang dewasa muda unuk merumuskan tujuan hidupnya, untuk membangun identitas dan menjadi lebih mandiri sebelum bergabung dengan orang lain untuk membentuk sebuah keluarga baru (Carter dan M cGoldrick dalam Santrock, 2002)

Pasangan baru (new couple) adalah fase kedua dari siklus kehidupan keluarga, di mana dua individu dari dua keluarga yang berbeda bersatu untuk membentuk satu sistem keluarga yang baru. Fase ini tidak hanya melibatkan pembangunan satu sistem pernikahan baru, tetapi juga penyusunan kembali hubungan dengan keluarga jauh dan teman-teman untuk melibatkan pasangan.

Menjadi orangtua dan keluarga dengan anak (becoming parents and a family with children) adalah fase ketiga dalam siklus kehidupan keluarga. Memasuki fase ini menuntut orang dewasa untuk maju satu generasi dan menjadi pemberi kasih sayang untuk generasi yang lebih muda. Untuk dapat melalui fase ini menuntut komitmen waktu sebagai orangtua, memahami peran sebagai orangtua dan menyesuaikan diri dengan perubahan perkembangan pada anak (Santrock, 2002)

Azhari (2004) mengatakan motivasi adalah sesuatu daya yang menjadi pendorong seseorang bertindak dimana rumusan motivasi menjadi sebuah kebutuhan nyata dan merupakan muara dari sebuah tindakan.

Motivasi merupakan suatu yang menjadi pendorong yang akan membuat individu merealisasikan apa yang menjadi keinginan ataupun untuk memenuhi kebutuhan termasuk pada suatu tujuan tertentu.

Pengambilan keputusan untuk menikah selagi masih menjalani kuliah tidak lepas dari motivasi seseorang untuk menikah. Keputusan untuk menikah yang nantinya akan memasuki kehidupan pernikahan membutuhkan pemahaman dan penyesuaian diri baik dengan kehadiran pasangan, keluarga baru, anak, beban/tanggungjawab serta konflik dalam pernikahan.

Berdasarkan uraian dan teori di atas, maka dapat diajukan beberapa pertanyaan penelitian, seperti: 1).Apa motivasi seseorang untuk menikah diusia muda/diusia kuliah? 2). Faktor-faktor apa saja yang mendukung dari terbentuknya dan teraktualisasinya motivasi tersebut? 3). Bagaimana kehidupan setelah pernikahan?

\section{Metode}

Penelitian ini dilakukakn secara kualitatif dengan menggunakan wawancara pada tiga orang responden sebagai metode pengumpulan data. 
Data yang diperoleh dari hasil wawancara, catatan lapangan, dan dokumentasi, dikoordinasikan ke dalam kategori, menjabarkannya ke dalam unit-unit, melakukan sintesa, menyusun ke dalam pola, memilih mana yang penting dan akan dipelajari dan membuat kesimpulan sehingga mudah difahami oleh diri sendiri maupun orang lain (Sugiyono, 2007).

\section{Hasil Penelitian}

Berdasarkan penelitian yang telah dilakukan, maka diperoleh gambaran/ model mengenai pernikahan pada responden I, II, III seperti tertera berikut ini :

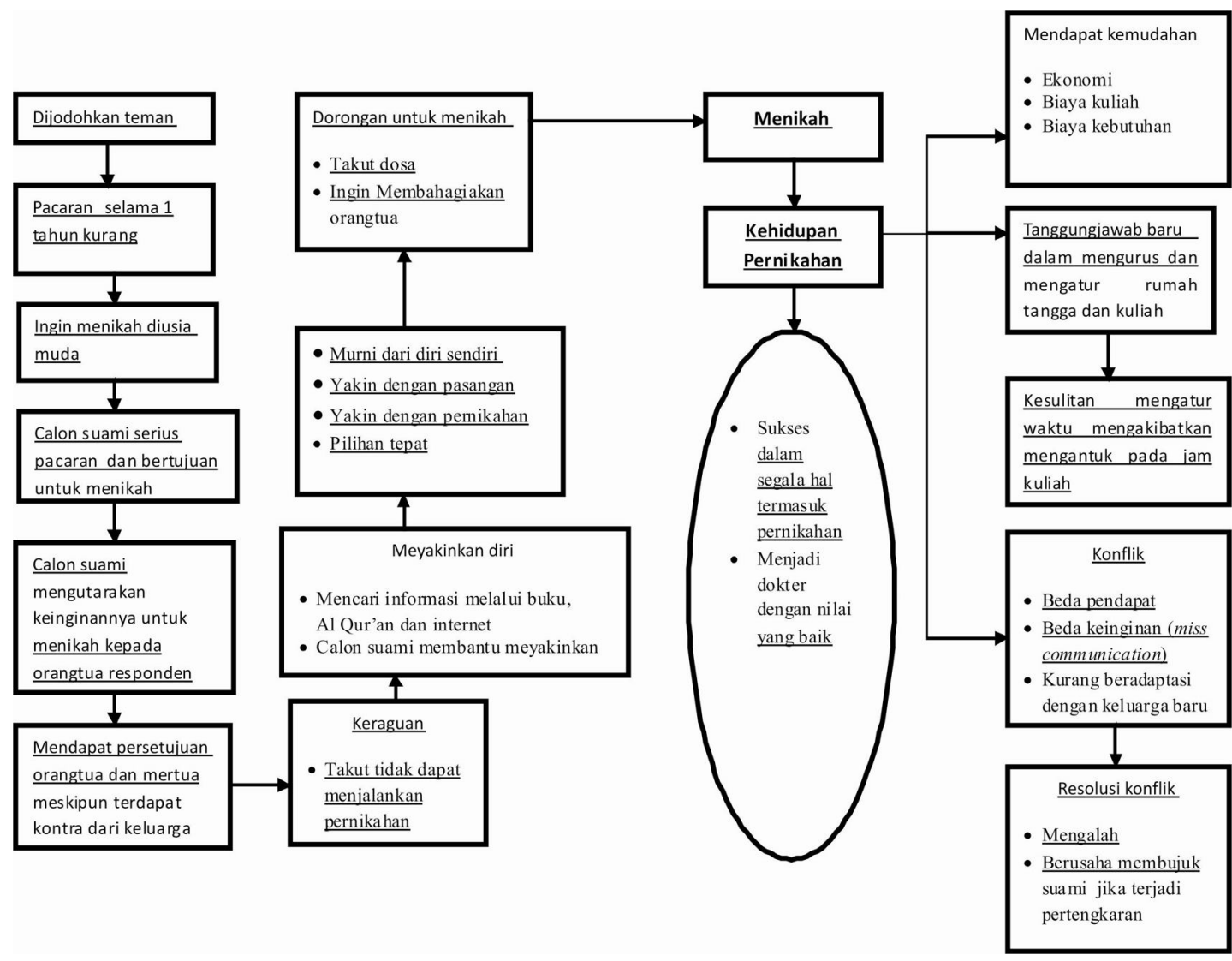

Gambar 1. Model pernikahan pada responden pertama 


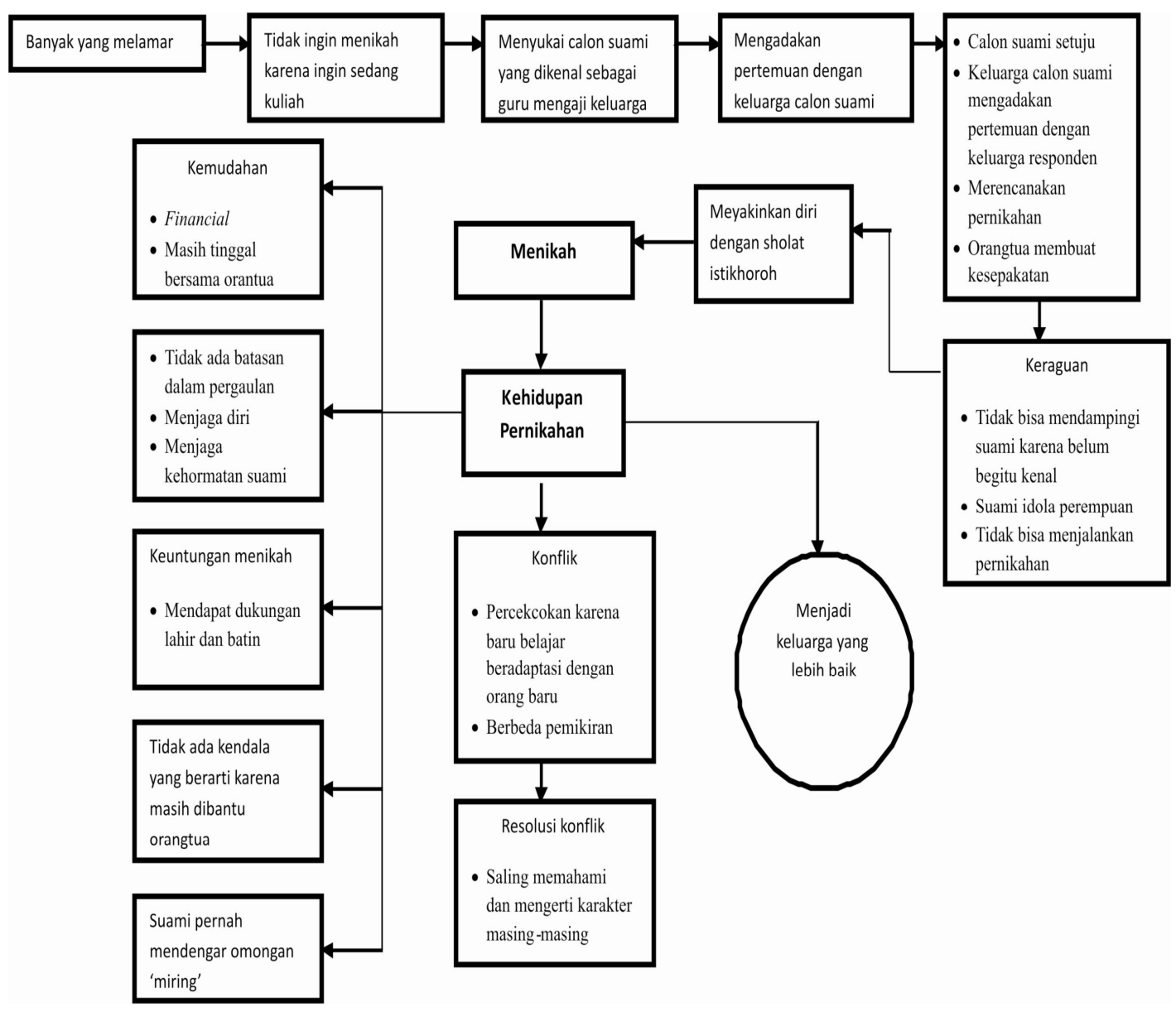

\section{Gambar 2. Model pernikahan pada responden kedua}




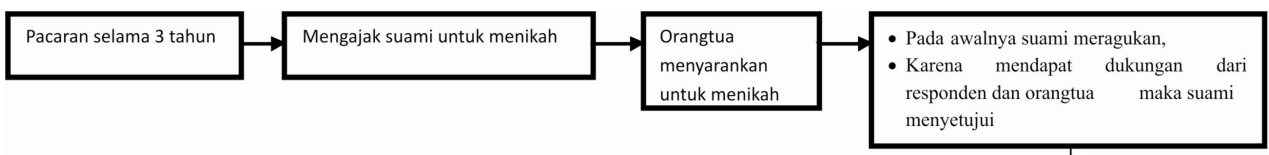

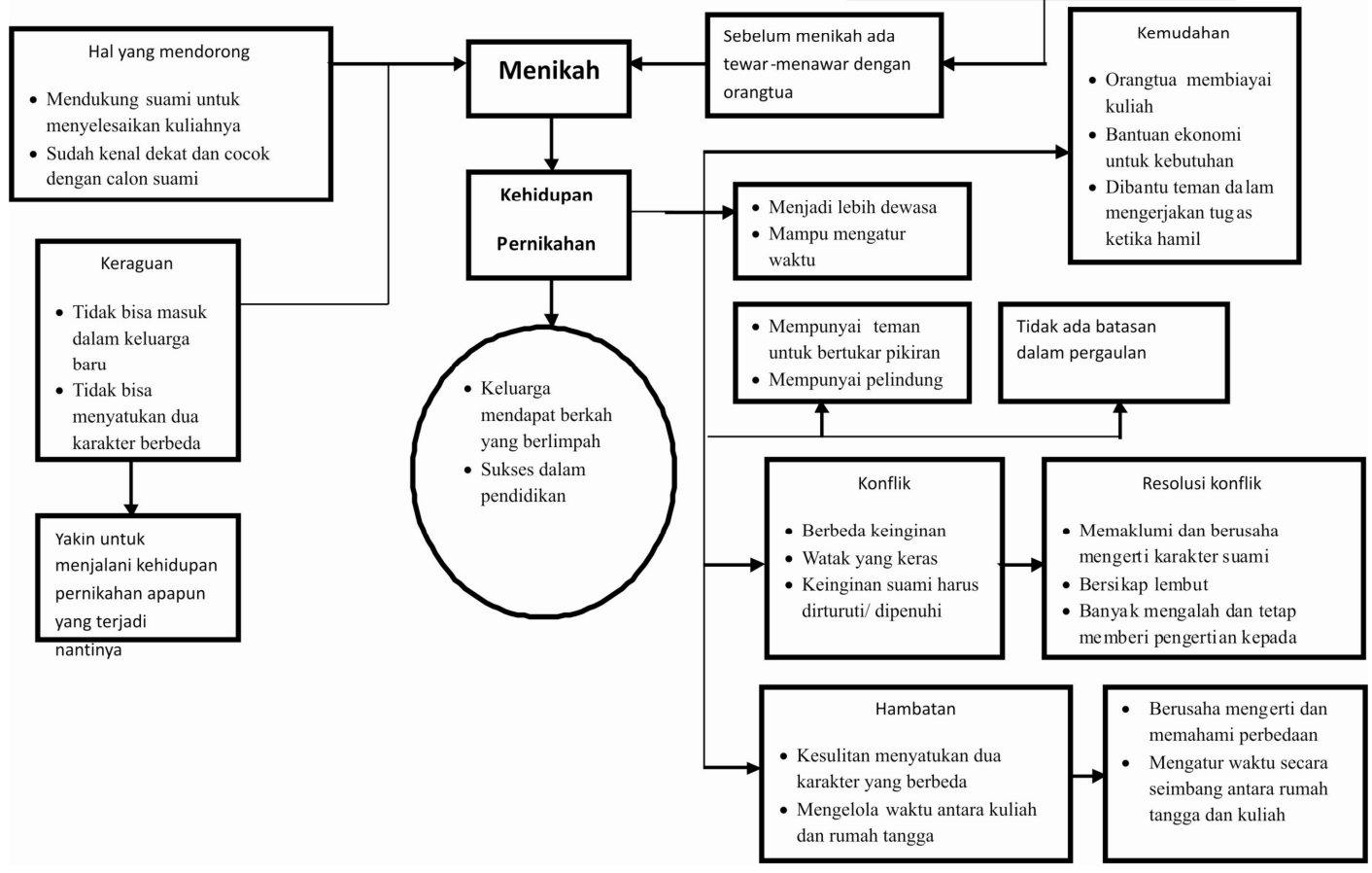

Gambar 3. Model pernikahan pada responden ketiga 


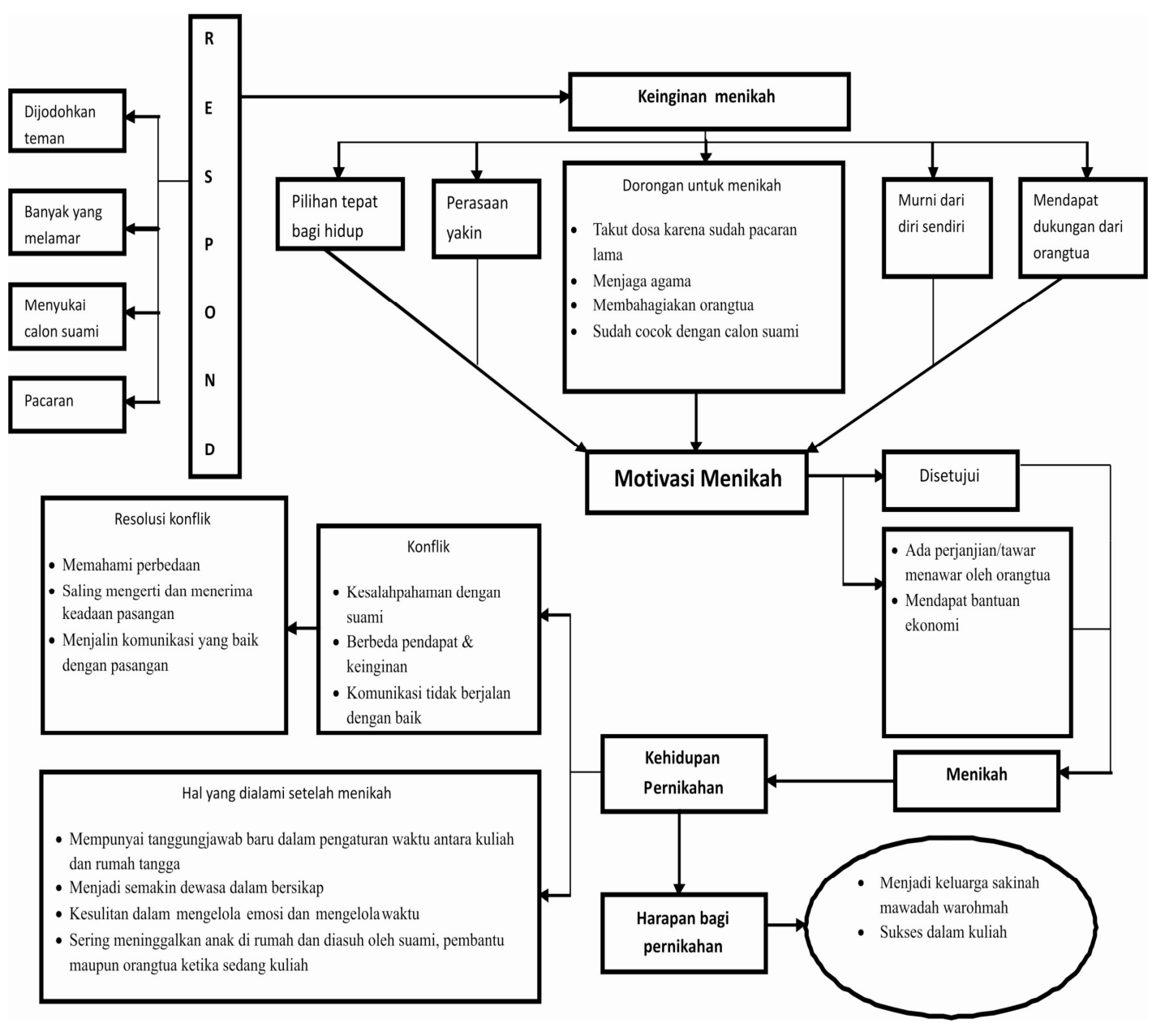

Gambar 4. Model pernikahan di kalangan mahasiswa S1 


\section{Pembahasan}

Berdasarkan gambaran model pernikahan di kalangan mahasiswa S1 tersebut dapat dijelaskan bahwa terbentuknya motivasi dimulai dari adanya keinginan yang kuat sehingga memacu seseorang untuk mewujudkan keinginan tersebut. Dalam hal ini keinginan responden adalah untuk menikah meskipun usia masih terbilang muda dan masih duduk dibangku kuliah. Keinginan atau kemauan adalah sesuatu yang keluar dari diri seseorang untuk diwujudkan. Keinginan responden untuk menikah didukung oleh perasaan yakin kepada calon suami dan juga yakin pada pernikahan yang akan dijalankan. Selanjutnya diikuti dengan kemurnian dari dalam diri yang dapat diartikan bahwa keinginan menikah benar-benar bersumber dari dalam diri dan tidak ada paksaan dari pihak lain. Ketika seseorang mempunyai keinginan yang kuat, maka seseorang itu akan termotivasi untuk mewujudkan keinginannya. Untuk mewujudkan motivasinya, maka harus ada kekuatan dari dalam diri maupun dari luar diri untuk merealisasikannya. Hal itu dapat dijelaskan dengan adanya dorongan. Dorongan yang dimaksud adalah wujud dari proses maupun usaha dan kekuatan dari dalam diri untuk mewujudkan keinginan. Dorongan yang paling besar yaitu ketakutan terhadap dosa yang yang akan diterima bila tidak mengakhiri pacaran yang sudah lama terjalin. Selain itu responden juga ingin menjaga agama. Menjalankan pernikahan ingin mengikuti syariat beragama dan sesuai dengan tuntunan agama. Dorongan untuk membahagiakan kedua orangtua juga menghiasi keinginan mereka untuk menikah. Membahagiakan orangtua juga ikut menjadi daftar penting bagi responden untuk menempuh jalan menikah diusia muda/usia kuliah. Disamping itu, kecocockan dengan suami pun menjadi dorongan bagi keinginan responden untuk mantap melangkah kejejang pernikahan. Mendapatkan restu atau persetujuan untuk menikah dari orangtua juga akan semakin menguatkan langkah para responden untuk menikah. Restu orangtua menjadi salah satu pendukung yang utama karena bagi mereka restu orangtua adalah yang terpenting. Para responden yakin bahwa dengan mengambil keputusan untuk menikah adalah pilihan yang tepat bagi hidup meski harus melewati rintangan yang mungkin dihadapi ketika menikah nantinya.

Keinginan responden untuk menikah direalisasikan ke dalam motivasi yang akan membantu mewujudkan keinginan responden untuk menikah. Setelah mewujudkan keinginan dan didorong dengan adanya motivasi, maka proses selanjutnya masuk ke dunia pernikahan. Untuk bisa menikah, tentunya harus sesuai dengan persetujuan orangtua. Dari data yang diperoleh, semua responden mendapat persetujuan dari orangtua masing-masing dan juga persetujuan dari pihak mertua. Selain itu, ketika hendak menikah orangtua responden membuat perjanjian/tawar menawar untuk memastikan kelangsungan kehidupan pernikahan anak mereka. Orangtua memberikan janji untuk tetap membiayai uang kuliah sampai dengan selesai. Selain itu orangtua juga ingin agar kuliah tetap dijalankan dan diselesaikan dengan baik meskipun sudah menikah.

Ketika individu telah melaksanakan pernikahan, secara otomatis akan memasuki kehidupan pernikahan dengan segala hal yang menghiasi pernikahan tersebut. Dari model di atas dapat dijelaskan bahwa dengan memasuki pernikahan akan ada tanggungjawab baru yang menyertai kehidupan. Hal ini sesuai dengan pendapat Desmita (2005) bahwa setiap pernikahan 
mengharapkan kebahagiaan dan ikatan pernikahan yang langgeng. Akan tetapi, sebuah pernikahan menuntut adanya penyesuaian diri terhadap tuntutan peran dan tanggungjawab baru dari kedua pasangan. Dengan adanya tanggungjawab, maka responden dan individu lainnya akan mendapat pembelajaran dalam hidup berumah tangga. Selain itu, para responden menjadi semakin dewasa dalam menyikapi hidup. Responden tetap berusaha memanage waktu agar dapat menyeimbangkan waktu antara rumah tangga dan kuliah. Dalam menjalankan kuliah, anak responden yang masih bayi sering ditinggal bersama suami, pembantu maupun dengan orangtua. Kehidupan pernikahan respondenpun tidak lepas dari peran orangtua dalam memberikan kemudahan. Seperti halnya memberikan bantuan ekonomi untuk memenuhi kebutuhan hidup buah hati mereka dalam menjalani kehidupan rumah tangga.

Menjalani kehidupan pernikahan pada akhirnya bermuara pada harapan/tujuan. Semua responden menginginkan untuk menjadi keluarga yang saking mawadah warohmah. Sebuah pengharapan untuk kehidupan yang lebih baik bagi diri, suami, anak dan keluarga dikemudian hari. Harapan mereka yang juga ingin diwujudkan adalah untuk mendapat kesuksesan dalam perkuliahan mengingat para responden masih menjadi mahasiswa aktif yang duduk dibangku perkuliahan dan mempunyai keinginan untuk segera menyelesaikan kuliah dengan nilai yang memuaskan/baik.

Menikah di usia muda ataupun di usia yang masih produktif untuk belajar memang menuai banyak resiko, terlebih untuk perempuan. Tetapi menikah adalah awal untuk menempa kedewasaan dan tanggungjawab sebagai seorang isrti ataupun suami. Bagaimana menjadikan kehidupan pernikahan sebagai berkah yang akan membawa nikmat di akhirat dan limpahan pahala serta ridho dari Alloh SWT bagi yang menikah dan berusaha untuk menjadikan pernikahan itu sebagai jalan untuk mengasah dan menambah potensi diri.

\section{Kesimpulan}

Untuk memperjelas hasil penelitian, maka disimpulkan bahwa motivasi tersebut muncul karena adanya dorongan yang kuat untuk mencapai keinginan atau tujuan yaitu sebuah pernikahan yang pada akhirnya akan bermuara pada harapan bagi kehidupan pernikahan nantinya. Dimulai dari keinginan yang kuat sehingga memacu seseorang untuk mewujudkan keinginan tersebut, maka muncullah motivasi. Motivasi menikah diantaranya adalah takut akan dosa, menjaga agama, ingin membahagiakan orangtua, sudah merasa yakin dengan pasangan maupun keputusan menikah serta yakin bahwa dengan menikah adalah pilihan tepat bagi hidup.

Motivasi menikah teraktualisasi karena didukung oleh faktor-faktor dari dalam diri maupun luar diri. Begitu juga dengan motivasi menikah. Berbagai hal dari dalam maupun dari luar diri responden mempengaruhi jalan mereka. Faktor-faktor yang mendukung terbentuk atau teraktualisasinya motivasi tersebut diantaranya adalah berasal dari dalam diri, yaitu keinginan untuk menikah di usia muda. Dengan keinginan yang kuat maka akan mendorong terbentuknya motivasi sehingga menimbulkan kekuatan untuk mencapai tujuan. 
Jika penjelasan di atas adalah faktor dari dalam diri, lain halnya dengan faktor-faktor dari luar diri. Hal ini terlihat dari persetujuan orangtua dan mertua. Dukungan yang sangat kuat dari orangtua membuat responden semakin kuat untuk melaksanakan pernikahan. Selain itu, dukungan yang diberikan juga terlihat dari pihak keluarga lainnya, meskipun masih terdapat pro dan kontra namun kekuatan yang diberikan oleh orangtualah yang paling berarti bagi para responden. Orangtua juga tidak serta merta melepaskan buah hati mereka menjalankan pernikahan begitu saja. Para orangtua juga memberikan jaminan seperti keuangan untuk membantu anak-anak mereka.

Setelah menjalani kehidupan pernikahan, orangtua dan mertua masih berperan penting dalam kehidupan perkawinan mereka. Walaupun sudah berstatus sebagai suami mereka belum dapat menafkahi keluarganya secara penuh, sehingga bantuan ekonomi dari orangtua dan mertua terhadap responden dan suaminya sangat membantu mereka dalam pemenuhan kebutuhan dan dalam mencapai cita-cita. Sebelum menikah semua orangtua responden berjanji akan tetap membiayai kuliah buah hati mereka sampai lulus kuliah. Hal ini juga yang membuat para pelaku nikah diusia muda/usia kuliah bertekad untuk bisa membuktikan kepada orangtua bahwa dengan menikah akan menambah prestasi belajar dan mampu memperoleh nilai yang memuaskan/baik. Selain itu nasehat dari orangtua ataupun mertua juga menjadi pembelajaran bagi responden untuk mengukuhkan kehidupan rumah tangga.

\section{Daftar Pustaka}

Abdussalam, Y. 2006. Trilogi Kuliah Makrifat, Bertanya Tuhan Tentang Jodoh. Yogyakarta : Media Insani

Adhim, M. F. 2002. Indahnya Pernikahan Dini. Jakarta : Gema Insani Press

Azhari, A. 2004. Psikologi Umum Dan Perkembangan. Jakarta : PT. M izan Publika

Dariyo, A. 2003. Psikologi perkembangan Dewasa Muda. Jakarta : PT. Gramedia Widiasarana Indonesia

Desmita. 2005. Psikologi Perkembangan. Bandung : PT. Remaja Rosdakarya

Munandar, S. C. U. 2001. Psikologi Perkembangan Pribadi dari Bayi Sampai Lanjut Usia. Jakarta : Universitas Indonesia (UI-Press)

Salim, H. H. 1980. Memilih Jodoh. Bandung : PT. Alma'arif

Santrock, J.W. 2002. Life-Span Development (Perkembangan Masa Hidup). Edisi Kelima Jilid Dua. Jakarta : Erlangga

Sugiyono. 2007. M etode Penelitian Kuantitatif Kualitatif dan R\&D. Bandung: Alfabeta.

Zein, A. Y dan Suryani, E. 2005. Psikologi Ibu Dan Anak. Yogyakarta : Fitramaya 
http://problematikaremaja.blogspot.com/2007/12.htm

www.noped.net

www.endonesa.net/utty/2008/20/09/ dibalik-trend-nikah-dini-di-kalangan-remaja-muslimperkotaan

www.bapeda-jabar.go.id.bapeda_design_informasi

www.kompas.com-2008-01-31-saatnya-mencegah-kanker-serviks 